\title{
Genetic diversity and population structure assessment using molecular markers and SPAR approach in Illicium griffithii, a medicinally important endangered species of Northeast India
}

\author{
Rajib Borah ${ }^{1,2}$, Atanu Bhattacharjee ${ }^{2}$, Satyawada Rama Rao ${ }^{2}$, Vineet Kumar ${ }^{3}$, Pradeep Sharma ${ }^{3}$,
} Krishna Upadhaya ${ }^{1}$ and Hiranjit Choudhury ${ }^{1 *}$ (D)

\begin{abstract}
Background: Illicium griffithii is an aromatic medicinal tree species that has been listed in the IUCN Red List as an endangered species. Dried seed pods of I. griffithii have a good market potential in the spices and pharmaceutical industries. Fruits are the potential source of shikimic acid and used for the production of oseltamivir (a drug against bird flu). However, in recent years, unscientific harvesting and rampant exploitation of the species has caused a negative and adverse effect on its natural population. Proper knowledge of genetic diversity and population structure is crucial to understand the population dynamics, adaptation, and evolutionary pattern of a particular species for conservation. It was from this view point that the present study was undertaken so as to compare the various types of DNA-based molecular markers namely RAPD, ISSR, DAMD, and SCoT by their efficiency and SPAR approach to evaluate the genetic diversity of I. griffithii as well as to analyze population genetic structure for conservation purpose.

Result: A total of 250 discernible bands were generated with 246 bands (98.40\%) being polymorphic in nature. All the primers in combination gave a mean polymorphic information content (PIC) of 0.81 and Rp value (resolving power) of 4.32. Nei's, Gst, and AMOVA analysis showed similar values of genetic differentiation among populations (Gst $=0.396, F_{S T}=0.30$, respectively), revealing a low level of genetic differentiation among the eight sampled populations. I. griffithii with an estimated gene flow value of $\mathrm{Nm}=0.761$ was significantly low among populations. Clustering pattern obtained with Bayesian structure and PCoA diagram revealed that intermixing of genetic material across populations is only possible when the populations lie close to each other. This is further validated with UPGMA clustering method where a positive correlation of genetic variability with geographical distance among closely related populations could be clearly seen.
\end{abstract}

\footnotetext{
* Correspondence: hiranjit_c@yahoo.com

1 Department of Basic Sciences and Social Sciences, School of Technology,

North-Eastern Hill University, Shillong, Meghalaya 793022, India

Full list of author information is available at the end of the article
}

\section{Springer Open}

(c) The Author(s). 2021 Open Access This article is licensed under a Creative Commons Attribution 4.0 International License, which permits use, sharing, adaptation, distribution and reproduction in any medium or format, as long as you give appropriate credit to the original author(s) and the source, provide a link to the Creative Commons licence, and indicate if changes were made. The images or other third party material in this article are included in the article's Creative Commons licence, unless indicated otherwise in a credit line to the material. If material is not included in the article's Creative Commons licence and your intended use is not permitted by statutory regulation or exceeds the permitted use, you will need to obtain permission directly from the copyright holder. To view a copy of this licence, visit http://creativecommons.org/licenses/by/4.0/. 
Conclusion: The result aids in the identification, collection, and preservation of diverse germplasm of I. griffithii from Arunachal Pradesh and Meghalaya of Northeast India. This would further help in understanding the population structure and genetic diversity among other Illicium species in order to formulate effective conservation strategies for the improvement of this endangered taxa.

Keywords: Illicium griffithii, Markers, Shikimic acid, Oseltamivir, Genetic diversity, SPAR

\section{Background}

The Northeast Himalayan range in India is one of the major biodiversity hotspots that harbor numerous endemic and endangered species having medicinal and economic importance. The wide altitudinal and climatic variations favor the existence of different forest types creating a favorable niche to considerable number of medicinal plants and herbs in particular. The importance of medicinal plants was although overlooked in the past, presently they are valued as an affordable healthcare supply aiding to the economic growth of the country. According to a WHO report, over $80 \%$ of the world population relies upon plant based traditional medicines for primary healthcare [1]. However, medicinal plants which form the basis for modern drug discoveries around the world are a living and exhaustible resource if not used sustainably. Presently, with the increase in the market demand for modern drug manufacturing, the medicinal plants are exploited without concern for their regeneration and conservation. Due to over exploitation and various adverse anthropogenic factors, the forest cover is steadily shrinking and certain medicinal plants have become endangered [2]. Approximately 90\% of the plant species used in the herbal industry is extracted from the wild and majority of these comes from the Himalayan region [3, 4]. Therefore, a large number of species are listed in IUCN Red Lists from this region. Illicium griffithii Hook. F. \& Thoms. belonging to the family Illiciaceae is one such important aromatic and medicinal tree species that has been listed in the IUCN Red List (Fig. 1) [5].

I. griffithii is an evergreen tree distributed at an altitude of 1700-3000 $\mathrm{m}$ across the temperate and subtropical forests of Arunachal Pradesh, Manipur, Meghalaya, Nagaland, Bangladesh, Bhutan, and Myanmar [6]. However, within these places, it has a confined and restricted distribution and the species is found in selected forest patches with favorable

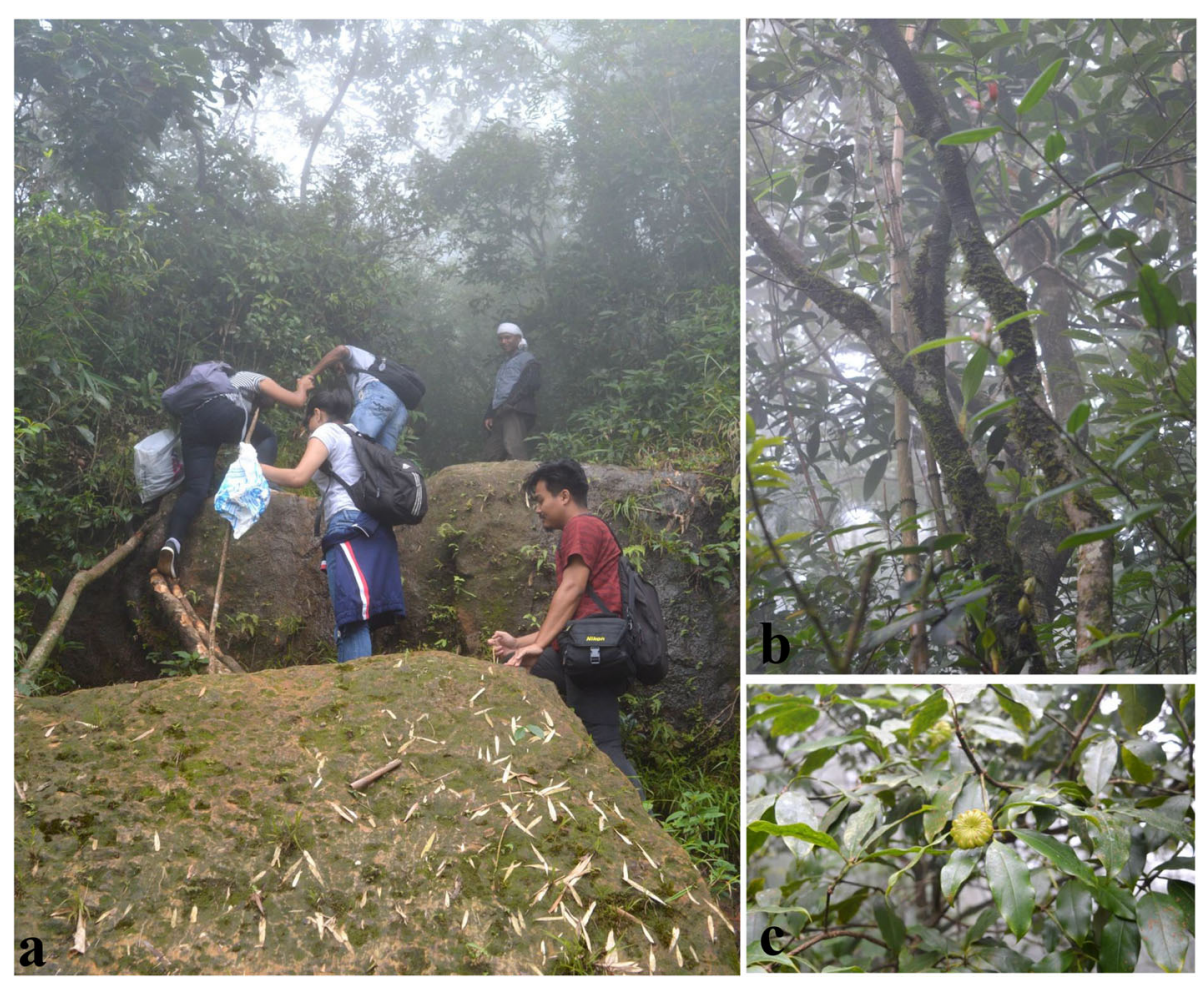

Fig. 1 Collection of samples from different locations; a field collection, b I. griffithii plant, c I. griffithii plant bearing fruits 
microclimatic condition [7]. The flowers of I. griffithii are obligate xenogamous, and thus only compatible pollen grains germinate on the stigma. The flowers are brooding sites for the midges and the young ovules are eaten by the larvae of the midges. Only $10 \%$ of the flowers mature into 13-seeded fruits and the remaining $90 \%$ of the flowers have seeds ranging from 1 to 5 [8]. The seeds show considerable dormancy period due to hard seed coat [9] and the seedling survivability rate is only $7 \%$ [8]. The above factors adversely affect the natural regeneration of the species in the wild. Dried seed pods of I. griffithii have a good market potential in the spices and pharmaceutical industries. They are used for medicinal preparations that cure abdominal pain, cough, food poisoning, vomiting, toothache, etc. Fruits are the potential source of shikimic acid and used for the production of Tamiflu (oseltamivir) which is an active drug against avian influenza or bird flu [10]. Besides, it is used as an aromatic, carminative, stimulant, glactogogic, and antifungal agent. The fruits are also used in incense, flavoring agent, food preservative, and to enhance the potency of alcohol. Woods from mature trees are used as fuel, poles for construction of houses, fencing, etc. and the remarkable economic potential of the plant has favored an important natural off-income source for the rural people [7]. Besides the reproductive bottlenecks as stated above, in recent years, habitat degradation, unscientific harvesting, and rampant exploitation of the species to meet the raising market demands has caused a negative and adverse effect on its natural populations. I. griffithii with its poor regeneration in the wild, localized natural growth, high anthropogenic pressure, and intangible efforts for conservation have resulted the species to be categorized as critically endangered species in Meghalaya and endangered in Arunachal Pradesh $[8,11]$. In order to conserve the gene pool, it is crucial to understand the genetic makeup of this important species. Proper knowledge of genetic diversity and population structure not only enhances our understanding of population dynamics, adaptation, and evolution of a particular species but also provides useful information for its conservation. Presently, various PCR-based molecular markers that are often based on non-coding DNA regions have proved beneficial to assess the genetic diversity among different plant species [12]. DNA-based molecular markers have various advantages over traditional methods and can effectively reveal the subtle variability at genetic levels with consistent data and authenticity. Polymerase chain reaction (PCR)-based single primer amplification reaction (SPAR) approach includes markers like random amplified polymorphic DNA (RAPD), inter-simple sequence repeats (ISSR), directed amplification of minisatellite DNA regions (DAMD), start codon targeted polymorphism (SCoT), SSR, etc., that collectively imparts an in-depth knowledge of the existing genetic diversity [13-18]. Since these markers are simple in nature, fast to perform, yield highly discriminative and reliable data, with a minimal cost involved, they are preferred by majority of plant biologists [19-22].

Previously, several studies have been carried out focusing on the biological factors causing the decline of I. griffithii population in the wild [8, 23-25]. But there is a large gap where genetic composition of $I$. griffithii that actually manifests in the form of morphological or reproductive variations concerning its survivability and evolution has been largely neglected. It was from this view point that the present study was undertaken so as to compare the various types of DNA based molecular markers namely RAPD, ISSR, DAMD, and SCoT by their efficiency and SPAR approach to evaluate the genetic diversity of I. griffithii as well as to analyze population genetic structure for conservation purpose.

\section{Methods \\ Collection of plant materials}

Plant materials for the study were collected from the natural habitats of Meghalaya and Arunachal Pradesh, India. Collected sites are tabulated below with their GPS readings (Table 1, Fig. 2). Young tender leaves (10-20) were randomly collected from each tree chosen at an interval of $30-50 \mathrm{~m}$ (a standard dependant on population size) according to the methods described by Roose et al. [26]. The sampling group included juvenile individuals of generative and pre-generative age (up to $10 \mathrm{~m}$ plant height). Sample size was maintained to a maximum of 30 individual per population from Arunachal Pradesh. However, in Meghalaya due to rarity of the species only a maximum of 10 individual per population could be maintained.

\section{DNA extraction and SPAR}

Genomic DNA was isolated from young leaves following the CTAB method [27] with minor modification. PCR was performed in $25 \mu \mathrm{L}$ mixture containing approximately $40 \mathrm{ng}$ DNA, $2.5 \mathrm{mM}$ each of the four dNTPs, $10 \times$ PCR buffer ( $\mathrm{Mg}^{2+}$ plus), $5 \mathrm{u} / \mu \mathrm{L}$ GoTaq DNA Polymerase (Takara), and $10 \mathrm{pmol}$ of primer. Reactions were performed in a thermocycler (Eppendorf) with the settings as given in Table 2 .

Amplified products were separated on $2 \%$ agarose gel stained with ethidium bromide in $1 \times$ TAE buffer and run for $3 \mathrm{~h}$ in an electrophoresis unit at $85 \mathrm{~V}$. DNA bands were visualized and photographed in a gel documentation unit 
Table. 1 Collection sites of I. griffithii from different areas of Meghalaya and Arunachal Pradesh

\begin{tabular}{|c|c|c|c|c|c|}
\hline SI. No. & Sites & Population ID & Sample size & GPS reading & Elevation (meter) \\
\hline 1 & Laitryngew Patch, Meghalaya & L & 6 & $\begin{array}{l}\text { N 251'32.09" } \\
\text { E 091 } 32^{\circ} 51.32^{\prime \prime}\end{array}$ & 1558 \\
\hline 2 & Umtong Patch, Meghalaya & U & 10 & $\begin{array}{l}\text { N } 25^{\circ} 24^{\prime} 43.06^{\prime \prime} \\
\text { E } 092^{\circ} 00^{\prime} 12.48^{\prime \prime}\end{array}$ & 1507 \\
\hline 3 & Bomdila Monestry, A. Pradesh & BM & 9 & $\begin{array}{l}\text { N } 27^{\circ} 16^{\prime} 06.52^{\prime \prime} \\
\text { E } 092^{\circ} 25^{\prime \prime} 06.86^{\prime \prime}\end{array}$ & 2526 \\
\hline 4 & Bomdila Patch 1, A. Pradesh & B1 & 18 & $\begin{array}{l}\text { N } 27^{\circ} 16^{\prime} 31.16^{\prime \prime} \\
\text { E 092 } 25^{\prime} 34.28^{\prime \prime}\end{array}$ & 2564 \\
\hline 5 & Bomdila Patch 2, A. Pradesh & B2 & 30 & $\begin{array}{l}\text { N } 27^{\circ} 16^{\prime} 48.13^{\prime \prime} \\
\text { E } 092^{\circ} 25^{\prime} 32.12^{\prime \prime}\end{array}$ & 2496 \\
\hline 6 & Bomdila Patch 3, A. Pradesh & B3 & 30 & $\begin{array}{l}\text { N } 27^{\circ} 16^{\prime} 36.63^{\prime \prime} \\
\text { E } 092^{\circ} 25^{\prime} 33.43^{\prime \prime}\end{array}$ & 2520 \\
\hline 7 & Bomdila Nursery, A. Pradesh & $\mathrm{BN}$ & 6 & $\begin{array}{l}\text { N } 27^{\circ} 16^{\prime} 39.15^{\prime \prime} \\
\text { E } 092^{\circ} 25^{\prime} 35.94^{\prime \prime}\end{array}$ & 2512 \\
\hline 8 & Tawang Nursery, A. Pradesh & TN & 6 & 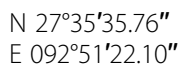 & 2850 \\
\hline
\end{tabular}

(Biostep DH-20, Germany) for final SPAR analysis. Each reaction was performed in two replicates and only clear reproducible bands were scored. Amplified products detected on the gels were recorded in a binary matrix where the fragments of similar size were represented as "1" for present or "0" for absent.

\section{Data analysis}

Genetic similarity based on Jaccard's coefficient was calculated using SIMQUAL module and a dendrogram was constructed using the NTSYS version 2.20 software package following the unweighted pair group method with arithmetic mean (UPGMA) option of the SAHN

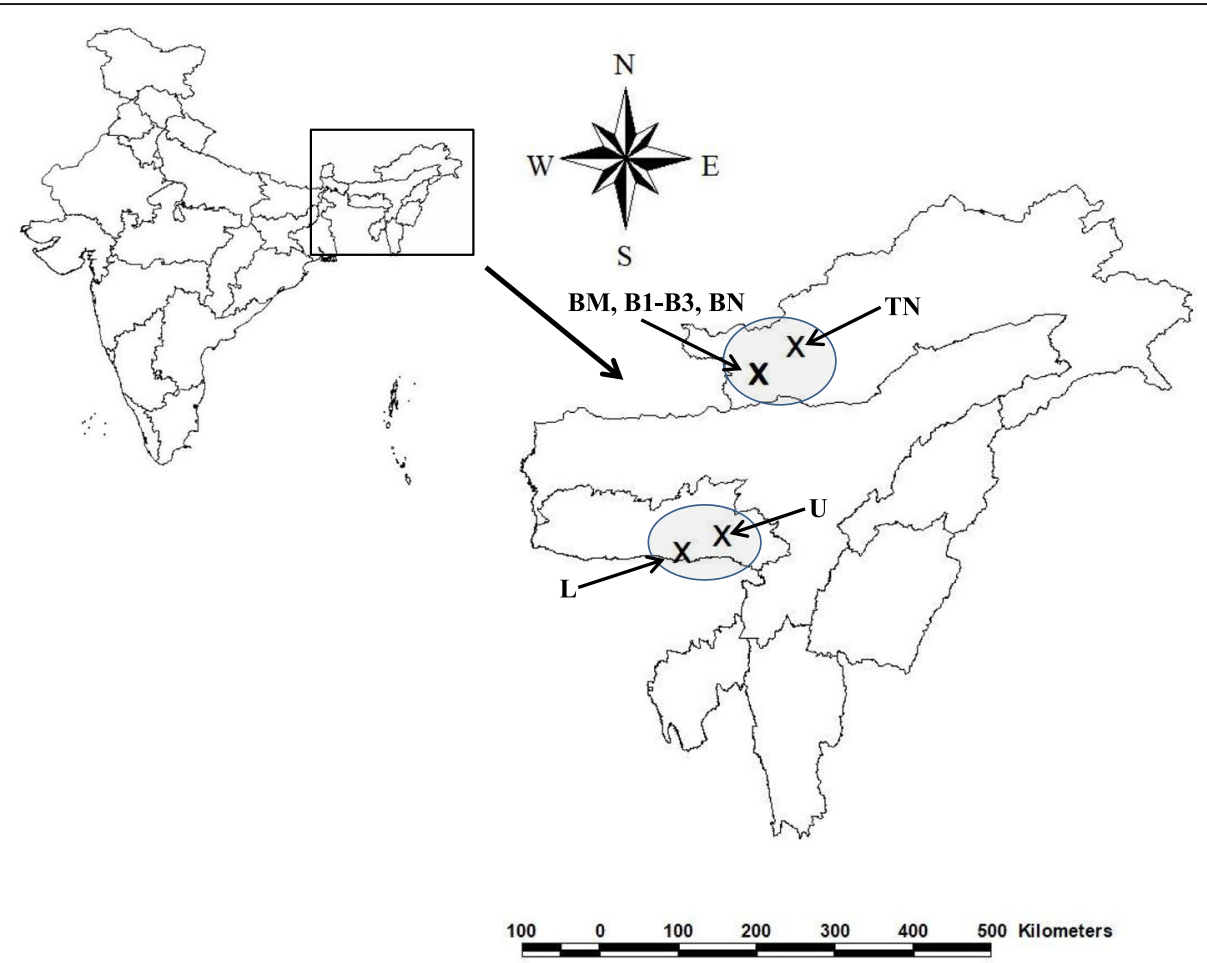

Fig. 2 Geographical distribution of collected I. griffithii genotypes from Meghalaya and Arunachal Pradesh (x represents collection sites) 
Table. 2 Reaction settings for the PCR cycles

\begin{tabular}{|c|c|c|c|c|c|c|}
\hline Programme & Initial denaturation & PCR cycle & & & Final extension & No. of cycles \\
\hline$\overline{\text { RAPD }}$ & $94{ }^{\circ} \mathrm{C}$ (3 min) & $94^{\circ} \mathrm{C}(45 \mathrm{~s})$ & $36{ }^{\circ} \mathrm{C}(1 \mathrm{~min})$ & $72{ }^{\circ} \mathrm{C}(2 \mathrm{~min})$ & $72{ }^{\circ} \mathrm{C}(7 \mathrm{~min})$ & 45 \\
\hline ISSR & $94{ }^{\circ} \mathrm{C}$ (3 min) & $92{ }^{\circ} \mathrm{C}$ (2 min $)$ & $38-54^{\circ} \mathrm{C}(1 \mathrm{~min})$ & $72{ }^{\circ} \mathrm{C}$ (2 min) & $72{ }^{\circ} \mathrm{C}$ (7 min $)$ & 40 \\
\hline DAMD & $94{ }^{\circ} \mathrm{C}$ (4 min) & $94{ }^{\circ} \mathrm{C}(1 \mathrm{~min})$ & $50{ }^{\circ} \mathrm{C}(2 \mathrm{~min})$ & $72{ }^{\circ} \mathrm{C}$ (2 min) & $72{ }^{\circ} \mathrm{C}(7 \mathrm{~min})$ & 40 \\
\hline SCoT & $95^{\circ} \mathrm{C}(5 \mathrm{~min})$ & $94^{\circ} \mathrm{C}$ (45 s) & $55^{\circ} \mathrm{C}(1 \mathrm{~min})$ & $72{ }^{\circ} \mathrm{C}$ (2 min) & $72{ }^{\circ} \mathrm{C}(7 \mathrm{~min})$ & 40 \\
\hline
\end{tabular}

module [28]. As per the binary metrices, principal coordinate analysis (PCoA) was performed to correlate genetic relationships among the populations using PAST version 3.16 [29]. To estimate the level of genetic polymorphism, the percentage of polymorphic amplicons (Pp \%), Shannon's index (I), and Nei's genetic diversity (the expected heterozygosity, $\mathrm{H}$ ), the programme POPGENE version 1.31 was used [30]. Gene flow $(\mathrm{Nm})$ was determined using the formula $\mathrm{Nm}=0.25 \times(1$ - Gst $)$ / Gst. The resolving capacity of the primers ( $\mathrm{pp}$ value) was calculated according to Prevost and Wilkinson [31].

To analyze the within and among population variations, analysis of molecular variance (AMOVA) at two hierarchical levels was performed using Arlequin version 3.01 [32]. F statistics $\left(\mathrm{F}_{\mathrm{ST}}\right)$ was applied to reveal differentiation between populations and its significance was evaluated following Wright [33]. Genetic population structure was investigated using Bayesian model-based clustering analysis with Structure 2.3.4 programme $[34,35]$ adapted to dominant markers. To determine the most likely number of groups $(K)$ in the data, a series of analyses were performed from $K=1$ through 11 , using 25,000 burn-in and 25,000 repetitions, with 10 iterations per $K$.

\section{Results}

The four marker systems (RAPD, ISSR, DAMD, and $\mathrm{SCoT}$ ) used in the present study revealed significant amount of polymorphism independent of each other at various levels proving the usefulness of the SPAR system used, to analyze diversity studies in I. griffithii. In the present study, out of 100 primers that were initially screened, a total of 28 primers were finally selected for analysis.

\section{RAPD analysis}

A total of 7 RAPD primers that were used for the analysis yielded 73 bands out of which 71 bands were polymorphic in nature (97.26\%). The primer OPH-19 produced maximum band number (13) with a polymorphic information content (PIC) value of 0.76 . The resolving power ( $\mathrm{Rp}$ value) of RAPD primers ranged between 2.59 and 5.49. The amplicon size ranged between 0.2 and $2 \mathrm{~kb}$ with an average of 10.42 amplicons per primer (Table 4, Fig. 3a). The genetic distance recorded using Jaccard's similarity coefficients ranged from 0.52 to 1.00 (Table 3, Fig. 3b).

\section{ISSR analysis}

There were 7 ISSR primers that were finally selected for genetic diversity analysis of I. griffithii. Out of 61 bands that were generated, 60 bands were found polymorphic (98.36\%). The primer SUNSRK-6 produced maximum band number (12) with a PIC value of 0.88 . The resolving power ( $\mathrm{Rp}$ value) of the primers ranged between 2.66 and 6.34. The amplicon size ranged between 0.2 and $2 \mathrm{~kb}$ with an average of 8.71 amplicons per primer (Table 4, Fig. 4a). The genetic distance recorded using Jaccard's similarity coefficients ranged from 0.59 to 1.00 (Table 3, Fig. 4b).

\section{DAMD analysis}

A total of 8 DAMD primers were finally selected for the analysis. The primers yielded 62 bands which were all polymorphic in nature (100\%). The primer Oligo 5 produced maximum band number (10) with highest polymorphic information content (PIC) of 0.95. The resolving power ( $\mathrm{Rp}$ value) of the primers ranged between 2.45 and 5.60. The amplicon size ranged between 0.2 and $2 \mathrm{~kb}$ with an average of 7.75 amplicons per primer (Table 4, Fig. 5a). The genetic distance recorded using Jaccard's similarity coefficients ranged from 0.51 to 1.00 (Table 3, Fig. 5b).

\section{SCoT analysis}

Six SCoT primers were selected for analysis that produced a total of 54 bands out of which 53 bands were polymorphic (98.14\%). Three SCoT primers (namely SCoT 14, 22, and 23) yielded maximum bands numbers (10) with PIC ranging between 0.76 and 0.84 . The resolving power ( $\mathrm{Rp}$ value) of the SCoT primers ranged between 3.30 and 4.57. The amplicon size ranged between 0.2 and $1.5 \mathrm{~kb}$ with an average of 9 amplicons per primer (Table 4, Fig. 6a). The genetic distance recorded using Jaccard's similarity coefficients ranged from 0.55 to 1.00 (Table 3, Fig. 6b).

\section{Combined study of RAPD, ISSR, DAMD, and SCOT (SPAR analysis)}

To test the efficacy of the single primer-based amplification reactions commonly known as SPAR, the combined 


\section{a}

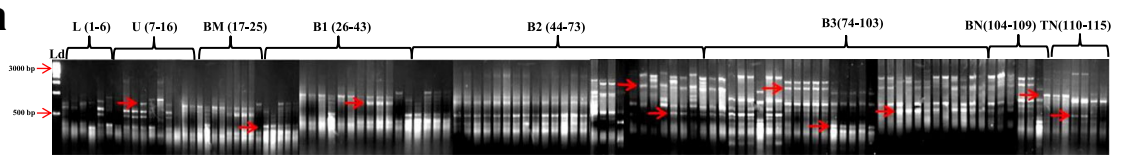

b

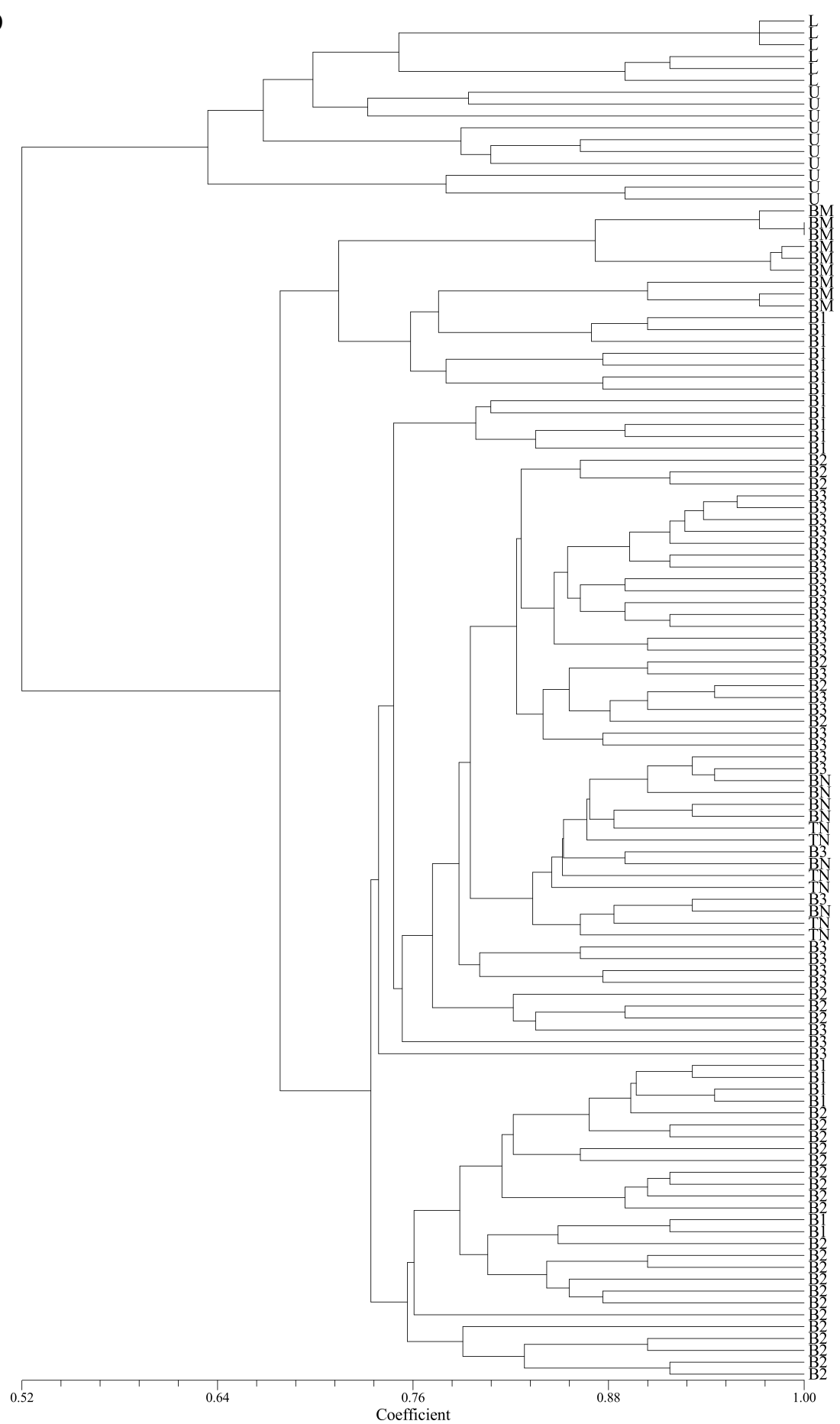

Fig. 3 RAPD profiles; a banding profile in I. griffithii populations using primer OPK-4, b genetic distance recorded with RAPD primers alone 
Table. 3 Individual as well as collective comparison of SPAR methods (RAPD, ISSR, DAMD and SCOT)

\begin{tabular}{lllllllll}
\hline $\begin{array}{l}\text { SI. } \\
\text { No. }\end{array}$ & $\begin{array}{l}\text { Name of SPAR } \\
\text { approach }\end{array}$ & $\begin{array}{l}\text { No. of } \\
\text { primer } \\
\text { used }\end{array}$ & $\begin{array}{l}\text { Total bands } \\
\text { amplified }\end{array}$ & $\begin{array}{l}\text { Average } \\
\text { bands/ } \\
\text { primer }\end{array}$ & $\begin{array}{l}\text { Size of } \\
\text { amplicons } \\
\text { (range kb) }\end{array}$ & $\begin{array}{l}\text { Total no. of } \\
\text { polymorphic } \\
\text { bands }\end{array}$ & $\begin{array}{l}\text { \% of } \\
\text { polymorphism }\end{array}$ & $\begin{array}{l}\text { Distance range } \\
\text { (Jaccard's } \\
\text { coefficient) }\end{array}$ \\
\hline 1 & RAPD & 7 & 73 & 10.42 & $0.2-1.5$ & 71 & 97.26 & $0.52-1.00$ \\
2 & ISSR & 7 & 61 & 8.71 & $0.2-2.0$ & 60 & 98.36 & $0.59-1.00$ \\
3 & DAMD & 8 & 62 & 7.75 & $0.2-2.0$ & 62 & 100.00 & $0.51-1.00$ \\
4 & SCOT & 6 & 54 & 9.00 & $0.2-2.0$ & 53 & 98.14 & $0.55-1.00$ \\
5 & RAPD + ISSR + & 28 & 250 & 8.92 & $0.2-2.0$ & 246 & 98.40 & $0.57-1.00$ \\
\hline
\end{tabular}

study of the above-mentioned primers (namely RAPD, ISSR, DAMD, and SCoT) was performed using the cumulative dataset in order to give a holistic approach to the study. The study yielded 250 amplicons out of which $246(98.40 \%)$ were polymorphic in nature (Table 3). The mean value of PIC (polymorphic information content) was found to be 0.81 with an $\mathrm{Rp}$ value (resolving power) of 4.32 (Table 4). The amplicon size ranged between 0.2 and $2.0 \mathrm{~kb}$ with an average of 8.92 amplicons per primer. The genetic distance recorded using Jaccard's similarity coefficients ranged from 0.57 to 1.00 (Table 3).

\section{Population structure}

The Pp\% (percentage of polymorphic loci) for a single population ranged from $41.20 \%(\mathrm{BN})$ to $76 \%$ (B2) with a total value of $98.40 \%$. The samples collected from B2 region have the highest observed number of alleles $(\mathrm{Na})$ being $(1.76 \pm 0.42)$ while that of $\mathrm{BN}(1.41 \pm 0.49)$ have the lowest $(\mathrm{Na})$ (Table 5). For all the populations, the effective number of alleles $(\mathrm{Ne})$ were consistently less than $\mathrm{Na}$ values showing a variation in the range of $1.26(\mathrm{BN})$ to $1.46(\mathrm{U})$ with an average of $1.55 \pm 0.30$. Population from $\mathrm{U}$ and $\mathrm{B} 1$ showed the highest Nei's gene diversity $(\mathrm{H})$ and Shannon index (I) $(\mathrm{H}=0.26 \pm 0.19 ; I=0.39 \pm$ 0.27 ) with the lowest being recorded in BN (Table 5). Mean coefficient of genetic differentiation among the eight sampled populations (Gst, assuming HardyWeinberg Equilibrium) was 0.396, showing that a higher level of population differentiation was distributed within populations.

This was validated with AMOVA analysis where higher variation $(69.37 \%)$ within populations as compared to lower variation (30.63\%) among populations was recorded with an F statistics $(\mathrm{FST}=0.30)$ (Table 6). The overall level of inferred gene flow $(\mathrm{Nm})$ was estimated at 0.761 , showing a relatively low migration rate between populations. Table 7 represents Nei's unbiased measure of genetic identity with genetic distance among the collected populations.

\section{Cluster/Tree analysis}

A dendrogram was constructed from the compiled data set of RAPD, ISSR, DAMD, and SCoT to represent the relationships among the collected populations using the UPGMA method of SAHN clustering. The populations under study were separated into two distinct clusters (Fig. 7). Cluster-I was again sub-clustered into Ia comprising population from $\mathrm{L}$ and $\mathrm{U}$ (Meghalaya) and $\mathrm{Ib}$ having population from BM (Arunachal Pradesh). Cluster-II further sub-clustered into IIa (with B1), IIb (B2 and B3), and IIc (BN and TN) all from Arunachal Pradesh population (Fig. 7). Bayesian clustering using structure analysis also revealed congruent results where the optimal $\Delta \mathrm{K}$ for $K=2$ is the best fit model to group the populations into two clusters (Fig. 8). The PCoA result derived using PAST showed similar clustering pattern that was consistent with the UPGMA and Bayesian clustering results generated in the study (Fig. 9).

\section{Discussion}

The assessment of the level and distribution of genetic variability in the wild plant species provides essential information regarding its evolutionary history and has a pivotal role in the conservation and maintenance of genetic resources [36-39]. Several important aspects of conservation biology concerning the loss of genetic diversity and restoration of threatened or endangered populations can only be addressed through detailed population genetics studies [40]. DNA-based molecular marker approaches are far more advanced over traditional methods with its high authenticity and consistency that can reveal even subtle genetic variability at DNA levels. However, the choice of techniques and proper markers are debatable and mostly depend on the nature of genetic structure of the species. The rate of evolutionary changes for a particular genomic region may differ according to species and therefore, it requires a distinctive approach to target various genomic areas as potential molecular genetic markers [41]. In this context, a comparison is required so as to decide which approach is most suitable for the taxon under study [42]. The 
Table. 4 Extent of polymorphism as revealed by RAPD, ISSR, DAMD and SCOT primers

\begin{tabular}{|c|c|c|c|c|c|c|c|c|c|}
\hline $\begin{array}{l}\text { Sl. } \\
\text { No. }\end{array}$ & $\begin{array}{l}\text { Name } \\
\text { of } \\
\text { primer }\end{array}$ & $\begin{array}{l}\text { Primer's } \\
\text { sequence }\end{array}$ & $\begin{array}{l}\text { Total } \\
\text { no. of } \\
\text { band }\end{array}$ & $\begin{array}{l}\text { No. of poly- } \\
\text { morphic } \\
\text { band }\end{array}$ & $\begin{array}{l}\text { No. of mono- } \\
\text { morphic } \\
\text { band }\end{array}$ & $\begin{array}{l}\% \text { of poly- } \\
\text { morphic } \\
\text { bands }\end{array}$ & $\begin{array}{l}\text { Resolv-ing } \\
\text { power } \\
(\mathrm{Rp})\end{array}$ & $\begin{array}{l}\text { PIC (Poly-morphic } \\
\text { information } \\
\text { content) }\end{array}$ & $\begin{array}{l}\text { Distance range } \\
\text { (Jaccard's } \\
\text { coefficient) }\end{array}$ \\
\hline \multicolumn{10}{|l|}{ RAPD } \\
\hline 1 & OPA-11 & $\begin{array}{l}\text { 5'-CAATCGCC } \\
\text { GT-3' }\end{array}$ & 9 & 8 & 1 & 88.88 & 4.60 & 0.88 & $0.57-1.00$ \\
\hline 2 & OPA-12 & $\begin{array}{l}\text { 5'-TCGGCG } \\
\text { ATAG-3' }\end{array}$ & 12 & 12 & 0 & 100.00 & 5.49 & 0.83 & \\
\hline 3 & OPA-13 & $\begin{array}{l}5^{\prime}-\text { CAGCACCC } \\
\text { AC- } 3^{\prime}\end{array}$ & 11 & 11 & 0 & 100.00 & 5.00 & 0.87 & \\
\hline 4 & OPB-1 & $\begin{array}{l}\text { 5'-GTTTCGCT } \\
\text { CC-3' }\end{array}$ & 11 & 11 & 0 & 100.00 & 4.64 & 0.80 & \\
\hline 5 & OPB-6 & $\begin{array}{l}\text { 5'-TGCTCTGC } \\
\text { CC-3' }\end{array}$ & 10 & 9 & 1 & 90.00 & 3,75 & 0.79 & \\
\hline 6 & OPH-19 & $\begin{array}{l}5^{\prime}-\mathrm{CTGACCAG} \\
\mathrm{CC}-3^{\prime}\end{array}$ & 13 & 13 & 0 & 100.00 & 5.32 & 0.76 & \\
\hline 7 & OPK-4 & $\begin{array}{l}5^{\prime}-\text { CCGCCCAA } \\
\text { AC-3' }\end{array}$ & 7 & 7 & 0 & 100.00 & 2.59 & 0.70 & \\
\hline \multicolumn{10}{|l|}{ ISSR } \\
\hline 8 & $\begin{array}{l}\text { SUNS } \\
\text { RK-5 }\end{array}$ & $\begin{array}{l}\text { 5'-GAGAGAGA } \\
\text { GAGAGAGATT- } \\
3^{\prime}\end{array}$ & 9 & 9 & 0 & 100.00 & 3.93 & 0.86 & \\
\hline 9 & $\begin{array}{l}\text { SUNS } \\
\text { RK-6 }\end{array}$ & $\begin{array}{l}\text { 5'-СTCTCTCTCT } \\
\text { СTCTCTTA-3' }\end{array}$ & 12 & 12 & 0 & 100.00 & 6.03 & 0.88 & \\
\hline 10 & $\begin{array}{l}\text { SUNS } \\
\text { RK-11 }\end{array}$ & $\begin{array}{l}5^{\prime}-\text { GGCGGCGG } \\
\text { CGGCGGCGGC- } \\
3^{\prime}\end{array}$ & 8 & 8 & 0 & 100.00 & 4.45 & 0.89 & \\
\hline 11 & $\begin{array}{l}\text { SUNS } \\
\text { RK-14 }\end{array}$ & $\begin{array}{l}5^{\prime}-\text {-ACACACA } \\
\text { CACAAC-3' }\end{array}$ & 10 & 10 & 0 & 100.00 & 6.34 & 0.88 & \\
\hline 12 & $\begin{array}{l}\text { SUNS } \\
\text { RK-14 }\end{array}$ & $\begin{array}{l}5^{\prime}-\text {-ACACACA } \\
\text { CACAGG-3' }\end{array}$ & 7 & 7 & 0 & 100.00 & 5.77 & 0.83 & \\
\hline 13 & $\begin{array}{l}\text { SUNS } \\
\text { RK-21 }\end{array}$ & $\begin{array}{l}\text { 5'-ACACACAC } \\
\text { ACACACACAG- } \\
3^{\prime}\end{array}$ & 8 & 8 & 0 & 100.00 & 4.95 & 0.74 & \\
\hline 14 & $\begin{array}{l}\text { SUNS } \\
\text { RK-22 }\end{array}$ & $\begin{array}{l}\text { 5'-ACACACAC } \\
\text { ACACACACT-3' }\end{array}$ & 7 & 6 & 1 & 85.71 & 2.66 & 0.70 & \\
\hline \multicolumn{10}{|c|}{ DAMD } \\
\hline 15 & URP 13R & $\begin{array}{l}\text { 5'-TACACGTC } \\
\text { TCGATCTACA- } \\
3^{\prime}\end{array}$ & 5 & 5 & 0 & 100.00 & 2.45 & 0.87 & \\
\hline 16 & Oligo 5 & $\begin{array}{l}\text { 5'-GACNGGNA } \\
\text { CNGG-3' }\end{array}$ & 10 & 10 & 0 & 100.00 & 2.97 & 0.95 & \\
\hline 17 & URP 38F & $\begin{array}{l}\text { 5'-AAGAGGCA } \\
\text { TाCTACCACC- } \\
3^{\prime}\end{array}$ & 6 & 6 & 0 & 100.00 & 3.40 & 0.88 & \\
\hline 18 & URP 9R & $\begin{array}{l}\text { 5'-ATGTGT } \\
\text { GCGATCAGTT } \\
\text { GC-3' }\end{array}$ & 7 & 7 & 0 & 100.00 & 4.57 & 0.79 & \\
\hline 19 & HBV 3 & $\begin{array}{l}\text { 5'-GGTGAAGC } \\
\text { SCAGGTG-3' }\end{array}$ & 9 & 9 & 0 & 100.00 & 3.94 & 0.73 & \\
\hline 20 & URP $25 F$ & $\begin{array}{l}\text { 5'-GATGTGTTCT } \\
\text { TGGAGCCT-3' }\end{array}$ & 8 & 8 & 0 & 100.00 & 4.53 & 0.79 & \\
\hline 21 & Oligo 2 & $\begin{array}{l}\text { 5'-CTCTGGGT } \\
\text { GTCGTGC-3' }\end{array}$ & 9 & 9 & 0 & 100.00 & 5.60 & 0.69 & \\
\hline 22 & HVY & $\begin{array}{l}\text { 5'-GCCTITCC } \\
\text { CGAG-3' }\end{array}$ & 8 & 8 & 0 & 100.00 & 4.33 & 0.69 & \\
\hline
\end{tabular}


Table. 4 Extent of polymorphism as revealed by RAPD, ISSR, DAMD and SCoT primers (Continued)

\begin{tabular}{|c|c|c|c|c|c|c|c|c|c|}
\hline $\begin{array}{l}\text { Sl. } \\
\text { No. }\end{array}$ & $\begin{array}{l}\text { Name } \\
\text { of } \\
\text { primer }\end{array}$ & $\begin{array}{l}\text { Primer's } \\
\text { sequence }\end{array}$ & $\begin{array}{l}\text { Total } \\
\text { no. of } \\
\text { band }\end{array}$ & $\begin{array}{l}\text { No. of poly- } \\
\text { morphic } \\
\text { band }\end{array}$ & $\begin{array}{l}\text { No. of mono- } \\
\text { morphic } \\
\text { band }\end{array}$ & $\begin{array}{l}\% \text { of poly- } \\
\text { morphic } \\
\text { bands }\end{array}$ & $\begin{array}{l}\text { Resolv-ing } \\
\text { power } \\
\text { (Rp) }\end{array}$ & $\begin{array}{l}\text { PIC (Poly-morphic } \\
\text { information } \\
\text { content) }\end{array}$ & $\begin{array}{l}\text { Distance range } \\
\text { (Jaccard's } \\
\text { coefficient) }\end{array}$ \\
\hline \multicolumn{10}{|l|}{ SCOT } \\
\hline 23 & SCOT-1 & $\begin{array}{l}\text { 5'-CAACAATG } \\
\text { GCTACCACCA- } \\
3^{\prime}\end{array}$ & 8 & 8 & 0 & 100.00 & 3.56 & 0.84 & \\
\hline 24 & SCOT-2 & $\begin{array}{l}5^{\prime}-\text { CAACAATG } \\
\text { GCTACCACCC- } \\
3^{\prime}\end{array}$ & 8 & 8 & 0 & 100.00 & 3.30 & 0.90 & \\
\hline 25 & SCOT-13 & $\begin{array}{l}5^{\prime} \text {-ACGACATG } \\
\text { GCGACCATCG- } \\
3^{\prime}\end{array}$ & 8 & 8 & 0 & 100.00 & 4.57 & 0.86 & \\
\hline 26 & SCOT-14 & $\begin{array}{l}5^{\prime} \text {-ACGACATG } \\
\text { GCGACCACGC- } \\
3^{\prime}\end{array}$ & 10 & 10 & 0 & 100.00 & 4.41 & 0.84 & \\
\hline 27 & SCOT-22 & $\begin{array}{l}5^{\prime} \text {-AACCATGG } \\
\text { CTACCACCAC- } \\
3^{\prime}\end{array}$ & 10 & 10 & 0 & 100.00 & 4.57 & 0.80 & \\
\hline \multirow[t]{3}{*}{28} & SCOT-23 & $\begin{array}{l}5^{\prime}-\text { CACCATGG } \\
\text { CTACCACCAG- } \\
3^{\prime}\end{array}$ & 10 & 9 & 1 & 90.00 & 3.40 & 0.76 & \\
\hline & & Total & 250 & 246 & 4 & 98.40 & & & \\
\hline & & Average & 08.92 & 08.78 & 0.14 & & & & \\
\hline
\end{tabular}

present study deals with the collective use of four marker system (RAPD, ISSR, DAMD, and SCoT) to examine the extent of genetic variability among the natural populations of I. griffithii collected from Meghalaya and Arunachal Pradesh.

It was found that each marker system was capable of detecting significant genetic polymorphism among the $I$. griffithii populations proving its discriminating efficacy and applicability in the current study. DAMD markers were found to be the most effective with $100 \%$ polymorphic bands (Table 4). The range of $\mathrm{Rp}$ values and PIC content obtained with all other markers were also adequate confirming their genotype discriminating ability [31, 43]. However, a marker is only considered best when there is a fine focus on the repetitive sequences of a particular genome, including I. griffithii. Therefore, a combination of RAPDs (spanning the entire genome of the DNA), ISSRs/DAMDs (spanning selected repetitive sequences), and SCoTs (spanning the start codon regions) could be considered as suitable markers for more meaningful and holistic approach to the analysis of genetic variability. Several authors have stressed the advantages of using more than one class of molecular markers to estimate genetic diversity of threatened taxa $[44,45]$. Numerous reports are available where SPAR approach has been used extensively to understand the intra- as well as inter-level population variation among various plant species [21, 46-49]. In the present analysis, 28 SPAR markers used were capable of detecting a high level of genetic variation at the species level with $98.40 \%$ of bands being polymorphic (Table 4). The range of values that determine the genome composition in a population like allelic frequency $(\mathrm{Na}=$ observed no. of alleles and $\mathrm{Ne}=$ effective number of alleles), gene flow $(\mathrm{Nm})$, and Nei's genetic differentiation (Gst) varied significantly than the corresponding values reported earlier [50-53]. This may be attributed to the inherent genotypic differences or the combination of marker system used for analysis.

The value of Nei's genetic differentiation among populations (Gst) may range from zero to one, with a higher value indicating that a larger number of variations lie among various populations. In the present study, different methods (Nei's, Gst, and AMOVA analysis) showed similar values of genetic differentiation among populations (Gst $=0.396, \mathrm{~F}_{\mathrm{ST}}=0.30$, respectively), revealing a low level of genetic differentiation among the eight sampled populations of I. griffithii (Tables 5 and 6). Most of the out-crossing species, in particular, usually follow this pattern where higher levels of genetic diversity resides within populations and low genetic diversity is found among populations $[40,54,55]$. Also, it has been confirmed that in nature gene flow can be estimated as low (with $\mathrm{Nm}$ less than 1 ), moderate (Nm greater than 1 ), and extensive (Nm greater than 4 ) as reported by Kumar et al. [22]. I. griffithii with an estimated gene flow value of $\mathrm{Nm}=0.761$ was significantly low among populations which is a characteristic feature of rare and endangered species [56]. I. griffithii shows obligate xenogamy and the breeding system is mostly entomophilous (insects 
a

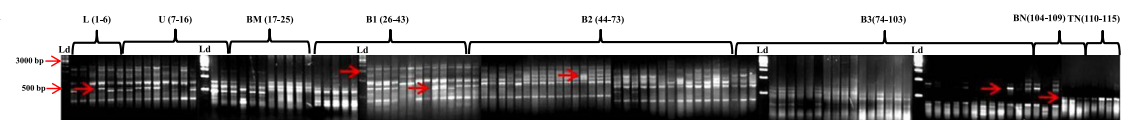

b

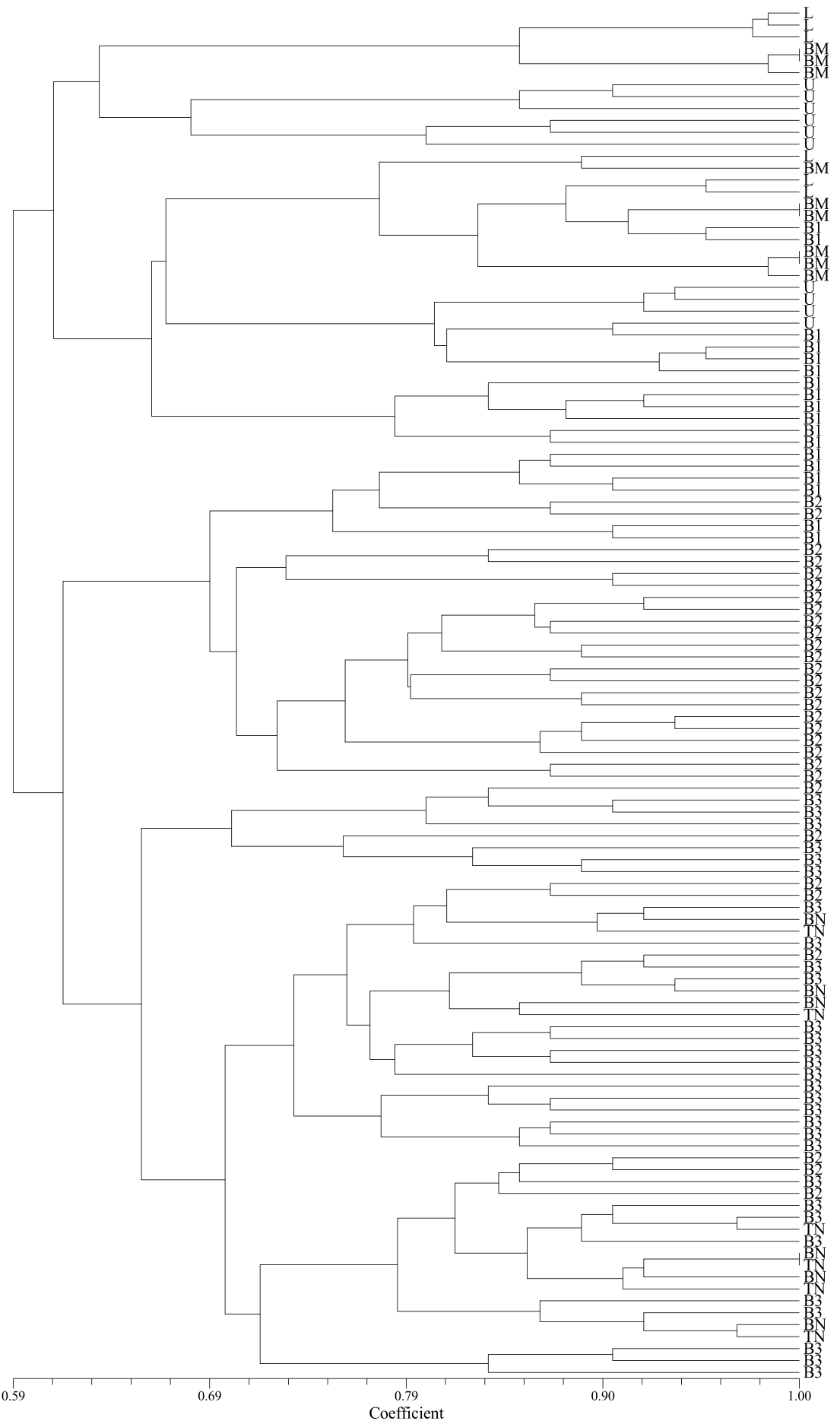

Fig. 4 ISSR profiles; a banding profile in I. griffithii populations using primer SUNSRK-14, b genetic distance recorded with ISSR primers alone 
a

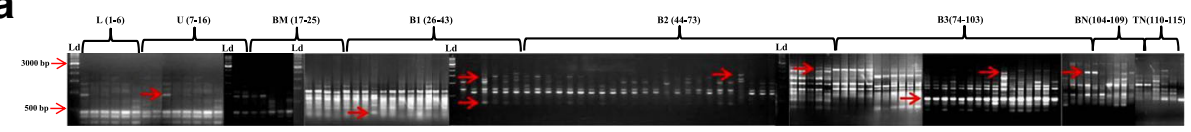

b

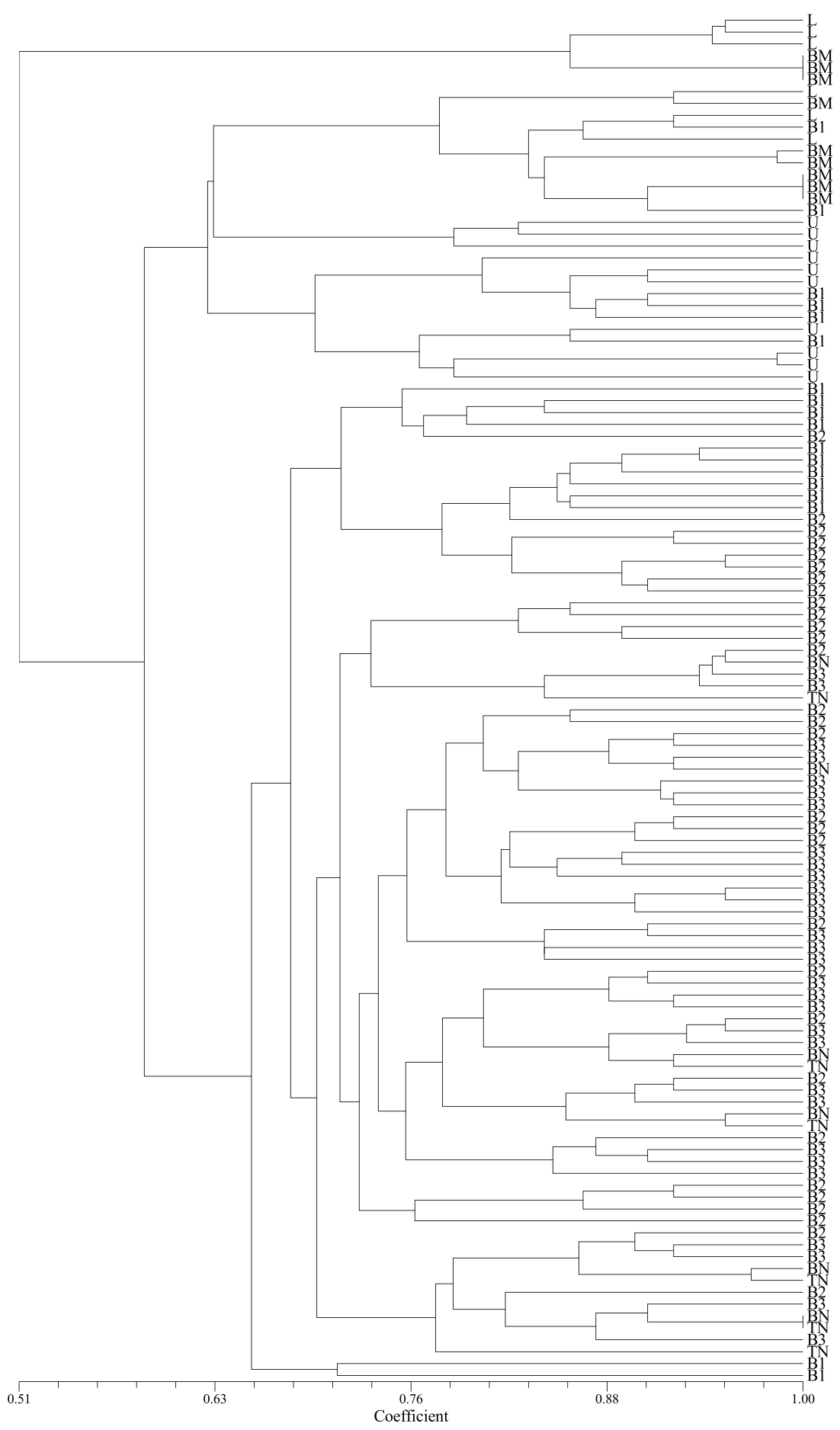

Fig. 5 DAMD profiles; a Banding profile in I. griffithii populations using URP 38F, b genetic distance recorded with DAMD primers alone 


\section{a}

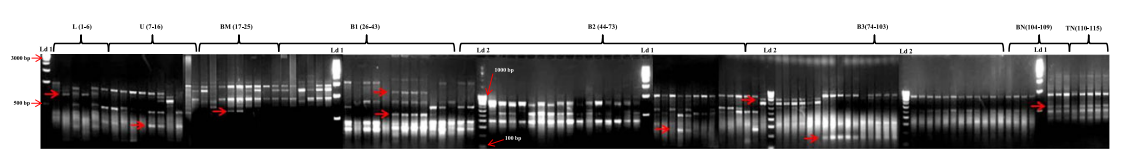

b

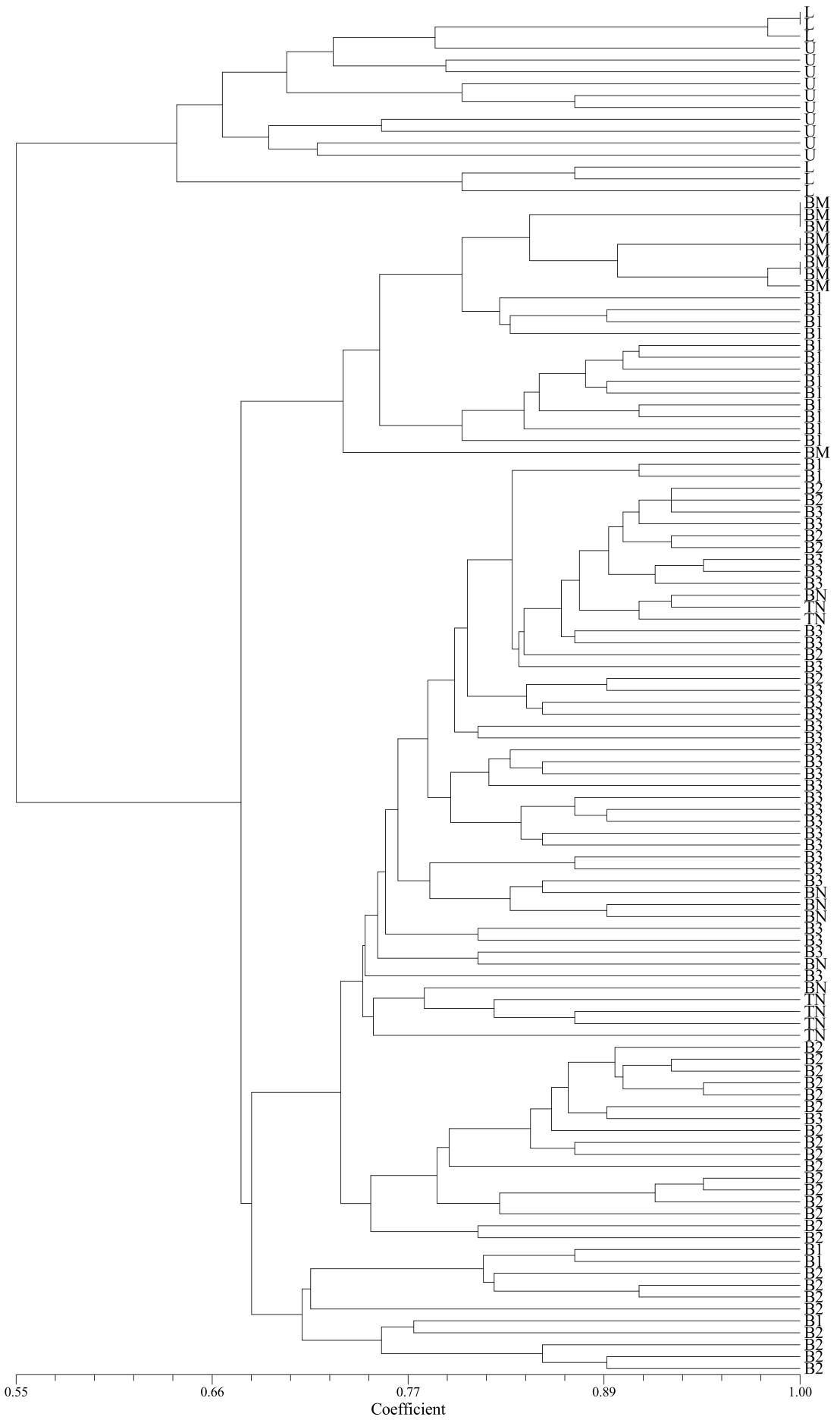

Fig. 6 SCOT profiles; a Banding profile in I. griffithii populations using primer SCOT-1, b Genetic distance recorded with SCOT primers alone 
Table. 5 Genetic variations as revealed through combined SPAR approach among eight populations of I. griffithii

\begin{tabular}{|c|c|c|c|c|c|c|c|c|c|c|c|}
\hline Population & $N$ & $\mathrm{Na} \pm \mathrm{SD}$ & $\mathrm{Ne} \pm \mathrm{SD}$ & $\mathrm{H} \pm \mathrm{SD}$ & $I \pm S D$ & $\mathrm{Pp}(\%)$ & $\mathrm{Np}$ & Hsp & Hpop & Gst & $\mathrm{Nm}$ \\
\hline L & 06 & $1.48 \pm 0.50$ & $1.38 \pm 0.43$ & $0.20 \pm 0.22$ & $0.29 \pm 0.31$ & 48.00 & 120 & & & & \\
\hline U & 10 & $1.66 \pm 0.47$ & $1.46 \pm 0.39$ & $0.26 \pm 0.20$ & $0.38 \pm 0.29$ & 66.00 & 165 & & & & \\
\hline $\mathrm{BM}$ & 09 & $1.44 \pm 0.49$ & $1.31 \pm 0.38$ & $0.17 \pm 0.21$ & $0.25 \pm 0.30$ & 44.40 & 111 & & & & \\
\hline B1 & 18 & $1.73 \pm 0.44$ & $1.44 \pm 0.36$ & $0.26 \pm 0.19$ & $0.39 \pm 0.27$ & 73.20 & 183 & & & & \\
\hline B2 & 30 & $1.76 \pm 0.42$ & $1.40 \pm 0.33$ & $0.24 \pm 0.17$ & $0.37 \pm 0.25$ & 76.00 & 190 & & & & \\
\hline B3 & 30 & $1.70 \pm 0.45$ & $1.36 \pm 0.34$ & $0.22 \pm 0.18$ & $0.34 \pm 0.26$ & 70.00 & 175 & & & & \\
\hline $\mathrm{BN}$ & 06 & $1.41 \pm 0.49$ & $1.26 \pm 0.35$ & $0.15 \pm 0.19$ & $0.23 \pm 0.28$ & 41.20 & 103 & & & & \\
\hline TN & 06 & $1.43 \pm 0.49$ & $1.27 \pm 0.36$ & $0.16 \pm 0.19$ & $0.24 \pm 0.28$ & 43.20 & 108 & & & & \\
\hline Total & 115 & $1.98 \pm 0.12$ & $1.55 \pm 0.30$ & $0.33 \pm 0.13$ & $0.50 \pm 0.17$ & 98.40 & 246 & 0.352 & 0.212 & 0.396 & 0.761 \\
\hline
\end{tabular}

$\mathrm{N}$ sample size, $\mathrm{Na}$ observed no. of alleles, Ne effective no. of alleles, $H$ Nei's genetic diversity, I Shannon's information index, $P p$ percentage of polymorphic loci, $N p$ number of polymorphic loci, Hsp total variability, Hpop variability within population, Gst diversity among populations, Nm gene flow 0.5 (1 - Gst) / Gst, SD standard deviation

Table. 6 Analysis of molecular variance (AMOVA) showing variation in the collected populations of I. griffithii

\begin{tabular}{|c|c|c|c|c|c|}
\hline Source of variation & Degrees of freedom & Sum of squares & Variance component & Percentage of variation & $\mathrm{F}_{\mathrm{ST}}$ \\
\hline Among populations & 07 & 1490.544 & 13.56 & 30.63 & \\
\hline Within populations & 107 & 3287.578 & 30.72 & 69.37 & \\
\hline Total & 114 & 4778.122 & 44.29 & 100 & 0.30 \\
\hline
\end{tabular}

Table. 7 Nei's unbiased measures of genetic identity and genetic distance among I. griffithii populations

\begin{tabular}{lllllllll}
\hline Population ID & L & U & BM & B1 & B2 & B3 & BN \\
\hline L & $* * * *$ & 0.8355 & 0.7770 & 0.7388 & 0.6949 & 0.6868 & 0.6546 & 0.6574 \\
U & 0.1797 & $* * * *$ & 0.7644 & 0.7951 & 0.7535 & 0.7513 & 0.7048 & 0.7017 \\
BM & 0.2523 & 0.2687 & $* * * *$ & 0.8532 & 0.7739 & 0.7660 & 0.7293 & 0.7315 \\
B1 & 0.3028 & 0.2293 & 0.1588 & $* * * *$ & 0.9191 & 0.8758 & 0.8387 & 0.8289 \\
B2 & 0.3641 & 0.2830 & 0.2563 & 0.0844 & $* * * *$ & 0.9372 & 0.8831 \\
B3 & 0.3757 & 0.2859 & 0.2666 & 0.1326 & 0.0648 & $* * * *$ & 0.9344 & 0.8691 \\
BN & 0.4238 & 0.3498 & 0.3156 & 0.1760 & 0.1243 & 0.0679 & $* * 22$ \\
TN & 0.4194 & 0.3543 & 0.3126 & 0.1877 & 0.1403 & 0.0919 & 0.0328 & 0.9677 \\
\hline
\end{tabular}

Nei's genetic distance (below diagonal) and genetic identity (above diagonal)

**** Signify zero distance since genetic distance is calculated within the population itself (e. g. between $\mathrm{L}$ and $\mathrm{L}=$ zero distance) 


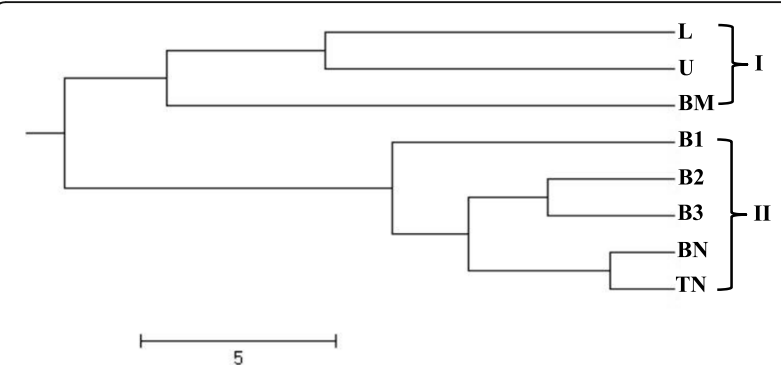

Fig. 7 UPGMA clustering of I. griffithii populations based on Jaccard's similarity

facilitated cross pollination) [25]. Insects have limited abilities to fly, and seed or pollen dispersal separated by long distances (as far as $25-100 \mathrm{~km}$.) is an unlikely or rare event. The lower level of gene flow among populations (Nm lesser than 1$)$ as seen in the present case is either due to population isolation caused by habitat fragmentation (natural or man-made) and/or lack of long-distance seed dispersers or pollinators (as the hilly terrain together with fragmented population restricts normal pollen transfer for short distant flyers). Our result conforms to the study of Duchok et al. [57] where they have considered the population pattern and regeneration ability of I. griffithii across disturbed area of Arunachal Pradesh. The study revealed clear dominance of adult trees and lowest number of seedlings across the study sites indicating poor regeneration of I. griffithii. Fruits on maturity expel their seeds to nearby areas which although are capable of germinating fails to convert into early sapling stage justifying the negative role of disturbance that creates an adverse niche for regeneration of I. griffithii [57]. Few seedlings that survive, again results in local regeneration favoring maximum variation retained within population. Clustering pattern obtained with Bayesian structure (Fig. 8) and PCoA diagram (Fig. 9) is also indicative of similar results and revealed that intermixing of genetic material across populations is only possible when the populations lie close to each

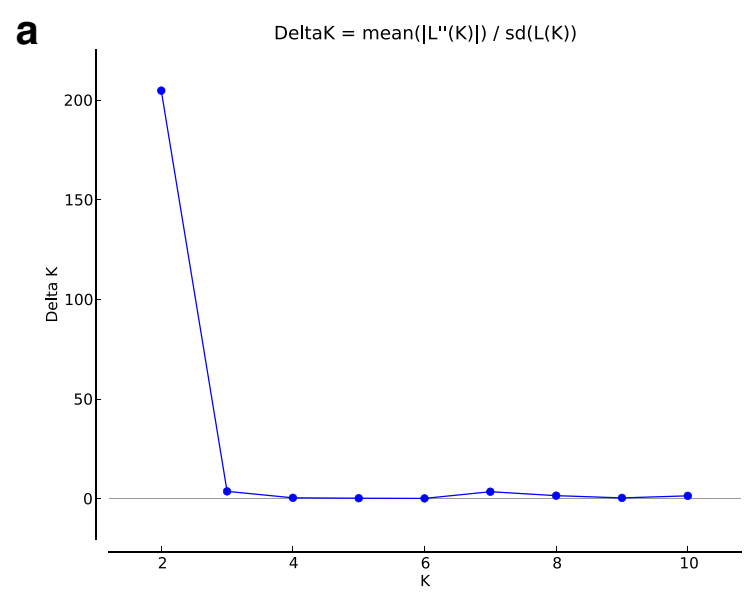

b
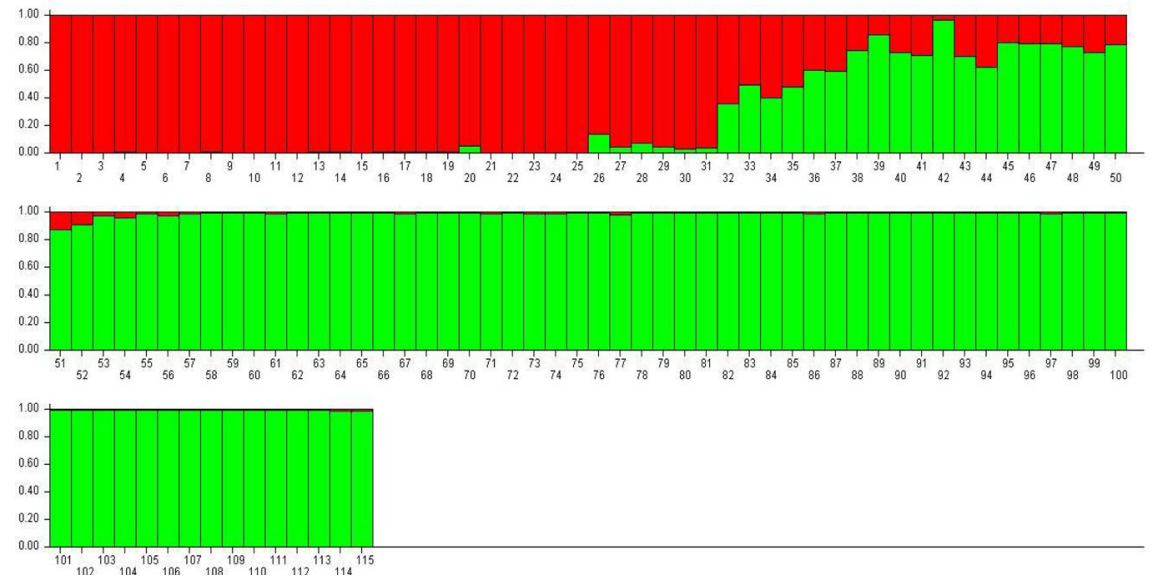

Fig. 8 Structure analysis based on Bayesian clustering of 8 populations (115 accessions); a plot showing the $\Delta K$ values; $\mathbf{b}$ genetic clustering estimated $(K=2)$ showing two genetic pools 


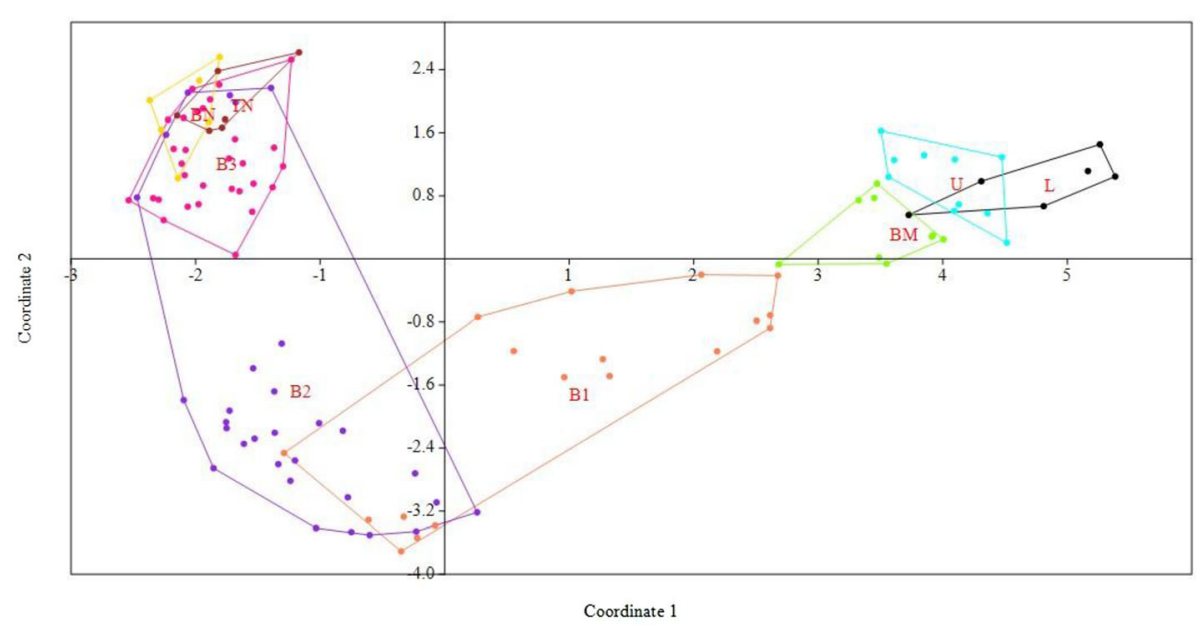

Fig. 9 Principal coordinate analysis (PCOA) revealing the clustering pattern of 8 populations (115 accessions) of I. griffithii

other. This is further validated with UPGMA clustering method where a positive correlation of genetic variability with geographical distance among closely related populations could be clearly seen (Fig. 7).

Among the eight populations sampled here, BM from Arunachal Pradesh showed relatively lower levels of genetic variation. This is due to its peripheral distribution range from the collected central populations (B1, B2, and B3) (Table 1). Populations located at the margins that are separated spatially from central populations are often believed to have smaller population sizes and lower genetic variations [58-60]. In addition, smaller sample size in population L (6), U (10) from Meghalaya, and BN (6) and TN (6) from Arunachal Pradesh could contribute to the lower genetic variation of the populations. From our field survey and ethno-botanic investigation, it was also observed that over collection of I. griffithii fruits to meet the increasing demands have negatively affected its natural population. Overharvesting of its wild resources has resulted in a sharp decline of the effective population number and size, with patches of local disappearance. Numerous studies are available which confirm the loss of genetic variation in wild populations due to overharvesting adversely impacting the evolutionary potential of a species to adapt to changing environments [61, 62]. Therefore, the observed pattern of genetic differentiation among the populations of I. griffithii may be attributed to all or some of the aforesaid factors mentioned in the study. Our results corroborate with the findings of other workers where moderate genetic differentiation among populations was observed in contrast to maximum genetic variability retained within populations [63-67].

\section{Conclusion}

Scientific approaches for conservation and sustainable utilization of plant resources require accurate assessment of the amount and distribution of genetic variation within and among populations [68]. Molecular marker techniques are reliable and far more advanced over traditional method to gain insight into the subtle genetic diversity affecting plant population structure [69, 70]. The present study showed the effectiveness of SPAR markers for the analysis of substantial genetic variability affecting genetic structure within natural populations of I. griffithii. The high genetic diversity within populations indicates that the best method for conservation would be to protect the existing natural populations and reintroduction of more individuals into the affected areas to maintain maximum diversity. Alternative techniques like macropropagation (cutting, grafting, etc.) and micropropagation (and/or in vitro seed germination) can be explored to effectively raise individuals from different populations and reintroduce them into the wild. The present study aids in identification, collection, and prioritization of genetically diverse germplasms of the threatened taxon I. griffithii for improvement and conservation.

\footnotetext{
Abbreviation

PIC: Polymorphic information content; Rp: Resolving power; RAPD: Random amplified polymorphic DNA; AFLP: Amplified fragment length polymorphism; DAMD: Directed amplification of minisatellite DNA regions; ISSR: Inter-simple sequence repeats; SCOT: Start codon targeted polymorphism; SPAR: Single primer amplification reaction; Pp: Percentage of polymorphic amplicons; I: Shannon's index; H: Nei's genetic diversity; Nm: Gene flow; Fst: Fixation index or F statistics; UPGMA: Unweighted pair group method with arithmetic mean; PCoA: Principal coordinate analysis
}

\section{Acknowledgements}

Authors are thankful to the Head of Office, BSI, Shillong, Meghalaya, India for the permission to consult the herbaria and identification of the species. Assistance received from Dr. Kemp and Dr. B. Bhatt, Forest Officials, Department of Environment \& Forests, Itanagar 791111, Arunachal Pradesh, India, in sample collection is acknowledged. 


\section{Plant authentication and identification}

The collected samples of the plant species were identified with the help of herbaria located at Botanical Survey of India (BSI), Eastern Regional Centre, Shillong, Meghalaya, India. The voucher specimen (88684, ASSAM) has been deposited in BSI, Shillong.

\section{Authors' contributions}

RB was the Junior Research Fellow who carried out fieldtrips, sample collection, experimentation, data collection, data analyses, and draft preparation. AB contributed in computational data analysis work. SRR contributed in molecular diversity work. VK assisted in partial conceptualization of the research work and procured the funding from the Funding Agency along with HC. PS also contributed in partial conceptualization of the research work. KU contributed in identification of the locations of occurrence of the species, guiding collection of samples from different locations and in writing of the manuscript. HC conceptualized the overall research and procured the funding from the Funding Agency, and was a major contributor in designing and conducting the experiments and final manuscript preparation. All authors have read and approved the manuscript for publication.

\section{Funding}

Financial grant received by the Principal Investigators from the Department of Biotechnology (DBT), Government of India vide No. BT/PR16719/NER/95/ 263/2015 dated 17.01.2017 is acknowledged.

\section{Availability of data and materials}

The data sets used and analyzed in the present study are presented in the article and the voucher specimen deposited in Botanical Survey of India (BSI), Eastern Regional Centre, Shillong, Meghalaya, India with an accession number.

\section{Declarations}

\section{Ethics approval and consent to participate}

Not applicable.

\section{Consent for publication}

Not applicable.

\section{Competing interests}

The authors declare that they have no competing interests.

\section{Author details}

'Department of Basic Sciences and Social Sciences, School of Technology, North-Eastern Hill University, Shillong, Meghalaya 793022, India. ²Department of Biotechnology and Bioinformatics, School of Life Sciences, North-Eastern Hill University, Shillong, Meghalaya 793022, India. ${ }^{3}$ Chemistry and Bioprospecting Division, Forest Research Institute, Indian Council of Forestry Research \& Education, Dehradun, Uttarakhand 248006, India.

\section{Received: 30 March 2021 Accepted: 18 July 2021}

\section{Published online: 10 August 2021}

\section{References}

1. Gopal NM, Tejaswini J, Mantry S, Kumar SA (2014) International standards of medicinal plants. Int J Innovative Pharm Sci Res 2(2498):2532

2. Hussain S, Hore DK (2008) Collection and conservation of major medicinal plants of Arunachal Pradesh. Indian For 12:1663-1679

3. Uniyal SK, Awasthi A, Rawat GS (2002) Current status and distribution of commercially exploited medicinal and aromatic plants in upper Gori valley, Kumaon Himalaya, Uttaranchal. Curr Sci 82(1246):1252

4. Singh MP, Dey S (2005) Indian Medicinal Plants. Satish Serial Publishing House, New Delhi

5. Saha D, Ved D, Ravikumar K, Haridasan K (2015) Illicium griffithii. The IUCN red list of threatened species 2015: e.T50126617A50131370. Accessed on 03 Apr 2017

6. Ariamuthu S, Balakrishna V, Kesavan A (2013) Estimation of shikimic acid from fruits of Illicium griffithii Hook. f. \& Thoms. and Illicium verum Hook. f. Int J Adv Pharm Res 4:1418-1425
7. Paul A, Kalita J, Khan ML, Tripathi OP (2013) Illicium griffithii. Hook, F. \& Thoms- A potential source of natural off farm income to the natural people of Arunachal Himalaya, India. Indian J Nat Prod Resour 4:131-137

8. Marbaniang EJ, Venugopal N, Verma S, Raina R, Khajuria A, Gautam K (2018) Floral biology and embryological studies are important for conservation of threatened plants having reproductive bottlenecks: a case study of Illicium griffithii Hook. f. \& Thomson. Curr Sci 114:576-587

9. Saha D (2008) Assessment and conservation of NTFPS with special emphasis on Illicium griffithii for sustainable livelihoods of the ethnic communities in Arunachal Pradesh, India (Academic Dissertation, Assam University, Silchar, Assam, India)

10. Choudhury H (2016) Illicium griffithii Hook. f. \& Thoms. a medicinally important threatened plant of Northeast India- Need for inventorization, characterization and propagation for improving economic and conservation status. In: Upadhaya K (ed) Biodiversity and Environmental Conservation. Discovery Publishing House Pvt. Ltd., New Delhi, pp 217-227

11. Bapu TD, Nimasow G (2017) Extraction of important medicinal plants and the need for conservation strategies in Eastern Himalayan Region, International conference on "Interplay of Economics, Politics and Society in the development of Nation", vol 1

12. Kalendar RN, Glazko VI (2002) Types of molecular-genetic markers and their application. Physiol Biochem Cult Plants 34:279-296

13. Williams JGK, Kubelik AR, Livak KJ, Rafalski JA, Tingey SV (1990) DNA polymorphisms amplified by arbitrary primers are useful as genetic markers. Nucleic Acids Res 18:6531-6535

14. Vos P, Hogers R, Bleeker M (1995) AFLP: a new technique for DNA fingerprinting. Nucleic Acids Res 23:4407-4414

15. Heath DD, Iwana GK, Delvin RH (1993) PCR primed with VNTR core sequences yield species specific patterns and hypervariable probes. Nucleic Acids Res 21:5782-5785

16. Meyer W, Mitchell TG, Freedman EZ, Vilgays R (1993) Hybridization probes for conventional DNA fingerprinting used as single primers in the polymerase chain reaction to distinguish strains of Cryptococcus neoformans. J Clin Microbiol 31:2274-2280

17. Zietkiewicz E, Rafalski A, Labuda D (1994) Genome fingerprinting by simple sequence repeat (SSR)- anchored polymerase chain reaction amplification. Genomics 20:176-183

18. Collard BC, Mackill DJ (2009) Start codon targeted (SCOT) polymorphism: a simple, novel DNA marker technique for generating gene-targeted markers in plants. Plant Mol Biol Rep 27:86-93

19. Bhattacharya E, Dandin SB, Ranade SA (2005) Single primer amplification methods reveal exotic and indigenous mulberry varieties are similarly diverse. J Biosci 30:669-677

20. Ranade SA, Rana TS, Narzary D (2009) SPAR profile and genetic diversity amongst pomegranate (Punica granatum L.) genotypes. Physiol Mol Biol Plants 15:61-70

21. Sharma SK, Rawat D, Kumar S, Kumar A, Kumaria S, Rao SR (2010) Single primer amplification reaction (SPAR) reveals intra-specific natural variation in Prosopis cineraria (L.) Druce. Trees 24:855-864

22. Kumar A, Mishra P, Singh SC, Sundaresan V (2014) Efficiency of ISSR and RAPD markers in genetic divergence analysis and conservation management of Justicia adhatoda L., a medicinal plant. Plant Syst Evol 300: 1409-1420

23. Saha D, Sundriyal RC (2010) Stand structure, phenology and fruit yield of Illicium griffithii in western Arunachal Pradesh, North East India. Indian J For 33:475-488

24. Upadhaya K, Mir AH, Iralu V (2018) Reproductive phenology and germination behavior of some important tree species of Northeast India. Proc Natl Acad Sci India Sect B Biol Sci 88:1033-1041

25. Marbaniang EJ, Venugopal N (2019) Pollination and breeding system in Illicium griffithii Hook. f. \& Thomson, an endangered tree species of Arunachal Pradesh, India. Int J Plant Reprod Biol 11:84-90

26. Roose ML, Feng D, Cheng FS, Tayyar Rl, Federici CT, Kupper RS, Goren R (2000) Mapping the citrus genome. In: Goldschmidt EE (ed) First International Citrus Biotechnology Symposium. Acta Hortic 535:25-32

27. Doyle JJ, Doyle JL (1990) Isolation of plant DNA from fresh tissue. Focus 12: 13-15

28. Rohlf FJ (2005) NTSYS-pc: Numerical taxonomy and multivariate analysis system, Version 2.2. Exeter Software, Appl Biostat Inc, New York

29. Hammer $\varnothing$, Harper DAT, Ryan PD (2001) PAST: Paleontological statistics software package for education and data analysis. Palaeontol Electron 4(1):9 
30. Yeh FC, Young RC, Boyle T (1999) Microsoft Window-based freeware for population genetic analysis (POPGENE, Ver. 1.31). URL: ftp://ftp.microsoft com/softlib/mslfiles/hpgl.exe.

31. Prevost A, Wilkinson MJ (1999) A new system of comparing PCR primers applied to ISSR fingerprinting of potato cultivars. Theor Appl Genet 98:107112

32. Excoffier L, Laval G, Schneider S (2005) Arlequin ver. 3.0: an integrated software package for population genetics data analysis. Evol Bioinform 1: 47-50

33. Wright S (1965) The interpretation of population structure by F-statistics with special regard to systems of mating. Evol 19:395-420

34. Pritchard JK, Stephens M, Donnelly P (2000) Inference of population structure using multilocus genotype data. Genet 155:945-959

35. Falush D, Stephens M, Pritchard JK (2003) Inference of population structure using multilocus genotype data: linked loci and correlated allele frequencies. Genet 164:1567-1587

36. Milligan BG, Leebens-Mack J, Strand AE (1994) Conservation genetics: beyond the maintenance of marker diversity. Mol Ecol 3:423-435

37. Ge S, Zhang DM, Wang HQ, Rao GY (1997) Allozyme variation in Ophiopogon xylorrhizus, an extreme endemic species of Yunnan, China. Conserv Biol 11:562-565

38. Francisco-Ortega J, Santos-Guerra A, Kim SC, Crawford DJ (2000) Plant genetic diversity in the Canary Islands: a conservation perspective. Am J Bot 87:909-919

39. Shah A, Li DZ, Gao LM, Li HT, Möller M (2008) Genetic diversity within and among populations of the endangered species Taxus fuana (Taxaceae) from Pakistan and implications for its conservation. Biochem Syst Ecol 36:183-193

40. Hamrick JL, Godt MJW (1996) Effects of life history traits on genetic diversity in plant species. Philos Trans R Soc Lond B Biol Sci 351:1291-1298

41. Biswas MK, Xu Q, Deng XX (2010) Utility of RAPD, ISSR, IRAP and REMAP markers for the genetic analysis of Citrus spp. Sci Hortic 124:254-261

42. Scariot V, De Keyser E, Handa T, De Riek J (2007) Comparative study of the discriminating capacity and effectiveness of AFLP, STMS and EST markers in assessing genetic relationships among evergreen azaleas. Plant Breed 126: 207-212

43. Smith JSC, Chin ECL, Shu H, Smith OS, Wall SJ, Senior ML, Ziegle J (1997) An evaluation of the utility of SSR loci as molecular markers in maize (Zea mays L.): comparisons with data from RFLPs and pedigree. Theor Appl Genet 95: 163-173

44. Chase M, Kesseli R, Bawa K (1996) Microsatellite markers for population and conservation genetics of tropical trees. Am J Bot 83:51-57

45. Esselman EJ, Jianqiang L, Crawford DJ, Windus JL, Wolfe AD (1999) Clonal diversity in the rare Calamagrostis porteri ssp. insperata (Poaceae): comparative results for allozymes and random amplified polymorphic DNA (RAPD) and inter simple sequence repeat (ISSR) markers. Mol Ecol 8:443-451

46. Yao X, Gao L, Yang B (2007) Genetic diversity of wild Cymbidium goeringii (Orchidaceae) populations from Hubei based on inter-simple sequence repeats analysis. Front Biol China 2:419-424

47. Parab GV, Krishnan S, Janarthanam MK, Sivaprakash KR, Parida A (2008) ISSR and RAPD markers assessed genetic variation of Aerides maculosum, an epiphytic orchid from Goa, India. J Plant Biochem Biotechnol 17:107-109

48. Kumar S, Kumaria S, Sharma SK, Rao SR, Tandon P (2010) Genetic diversity assessment of Jatropha curcas L. germplasm from Northeast India. Biomass Bioenergy 35:3063-3070

49. Machado Neto NB, Vieira LGE (2011) Assessment of genetic diversity in Cattleya intermedia Lindl. (Orchidaceae). Braz Arch Biol Technol 54:939-946

50. Qiu Y, Hong D, Fu C, Cameron K (2004) Genetic variation in the endangered and endemic species Changium smyrnioides (Apiaceae). Biochem Syst Ecol 32:583-596

51. Bhattacharyya P, Kumaria S, Kumar S, Tandon P (2013) Start codon targeted (SCOT) marker reveals genetic diversity of Dendrobium nobile Lindl., an endangered medicinal orchid species. Gene 529:21-26

52. Al-Qurainy F, Khan S, Nadeem M, Tarroum M (2015) SCoT marker for the assessment of genetic diversity in Saudi Arabian date palm cultivars. Pak J Bot 47:637-643

53. Ray A, Jena S, Haldar T, Sahoo A, Kar B, Patnaik J, Ghosh B, Panda PC, Mahapatra N, Nayak S (2019) Population genetic structure and diversity analysis in Hedychium coronarium populations using morphological, phytochemical and molecular markers. Ind Crop Prod 132:118-133
54. Hogbin PM, Peakall R (1999) Evaluation of the contribution of genetic research to the management of the endangered plant Zieria prostrata. Conserv Biol 13:514-522

55. Zawko G, Krauss SL, Dixon KW, Sivasithamparam K (2001) Conservation genetics of the rare and endangered Leucopogon obtectus (Ericaceae). Mol Ecol 10:2389-2396

56. Slatkin M (1985) Gene flow in natural populations. Annu Rev Ecol Syst 16: 393-430

57. Duchok R, Kent K, Khumbongmayum AD, Paul A, Khan ML (2005) Population structure and regeneration status of medicinal tree Illicium griffithii in relation to disturbance gradients in temperate broad-leaved forest of Arunachal Pradesh. Curr Sci 89:673-676

58. Blows MW, Hoffmann AA (1993) The genetics of central and marginal populations of Drosophila serrata. I genetic variation for stress resistance and species borders. Evol 47:1255-1270

59. Liu J, Wang L, Geng Y, Wang Q, Luo L, Zhong Y (2006a) Genetic diversity and population structure of Lamiophlomis rotata (Lamiaceae), an endemic species of Qinghai-Tibet Plateau. Genetica 128:385-394

60. Liu Y, Wang Y, Huang $H$ (2006b) High interpopulation genetic differentiation and unidirectional linear migration patterns in Myricaria laxiflora (Tamaricaceae), an endemic riparian plant in the three Gorges valley of the Yangtze River. Am J Bot 93:206-215

61. Nakagawa M (2004) Genetic diversity of fragmented populations of Polygala reinii (Polygalaceae), a perennial herb endemic to Japan. J Plant Res 117 355-361

62. Abbott RJ, Ireland HE, Rogers HJ (2007) Population decline despite high genetic diversity in the new allopolyploid species Senecio cambrensis (Asteraceae). Mol Ecol 16:1023-1033

63. Li A, Ge S (2006) Genetic variation and conservation of Changnienia amoena, an endangered orchid endemic to China. Plant Syst Evol 258:251-260

64. Zhang XM, Wen J, Dao ZL (2010) Genetic variation and conservation assessment of Chinese populations of Magnolia cathcartii (Magnoliaceae), a rare evergreen tree from the South-Central China hotspot in the Eastern Himalayas. J Plant Res 123(3): 321-331. https:/doi.org/10.1007/s10265-009-0278-9

65. Manners V, Kumaria S, Tandon P (2013) SPAR methods revealed high genetic diversity within populations and high gene flow of Vanda coerulea Griff ex Lindl (Blue Vanda), an endangered orchid species. Gene 519:91-97

66. Chen L, Chen F, He S, Ma L (2014) High genetic diversity and small genetic variation among populations of Magnolia wufengensis (Magnoliaceae), revealed by ISSR and SRAP marker. Electron J Biotechnol 17:268-274

67. Lamare A, Rao SR (2015) Efficacy of RAPD, ISSR and DAMD markers in assessment of genetic variability and population structure of wild Musa acuminata colla. Physiol Mol Biol Plants 21:349-358

68. Han J, Zhang W, Cao H, Chen S, Wang Y (2007) Genetic diversity and biogeography of the traditional Chinese medicine, Gardenia jasminoides, based on AFLP markers. Biochem Syst Ecol 35:138-145

69. Powell W, Morgante M, Andre C, Hanafey M, Vogel J, Tingey S, Rafalski A (1996) The comparison of RFLP, RAPD, AFLP and SSR (microsatellite) markers for germplasm analysis. Mol Breed 2:225-238

70. Ouborg NJ, Piquot Y, Van Groenendael JM (1999) Population genetics, molecular markers and the study of dispersal in plants. J Ecol 87:551-568

\section{Publisher's Note}

Springer Nature remains neutral with regard to jurisdictional claims in published maps and institutional affiliations. 